\title{
SABORES E SABERES AMAZÔNICOS
}

\author{
Narle Silva Teixeira \\ Faculdade Fucapi \\ narle.teixeira@fucapi.br \\ Weymarina Antonia Normando Cabral \\ Faculdade Fucapi \\ weyncabral@gmail.com \\ Anderson Marinho Correa \\ Faculdade Fucapi \\ anderson@tterra.com.br \\ Rainer Costa de Souza \\ Faculdade Fucapi \\ contatomlac@gmail.com
}

\begin{abstract}
Resumo: Uma característica do mundo moderno é a rápida e inegável disseminação das tecnologias de informação e de comunicação na sociedade. Este artigo, intitulado Sabores e Saberes Amazônicos, aborda um tema que envolve o Design da informação e de interação, de como as informações podem estar disponíveis de uma maneira que, além de adquirir conhecimentos, o usuário tenha experiências agradáveis. Apresenta a criação de interfaces para um aplicativo de culinária amazônica para dispositivos móveis, com metodologia baseada em Jesse James Garret. Conceituações de design de interação com ênfase na ergonomia, usabilidade e semiótica foram aplicadas. Os resultados foram interfaces leves e de navegabilidade simples, proporcionando um feedback o mais imediato possível, além de uma linguagem visual atraente a partir dos elementos da culinária e cultura do Amazonas.
\end{abstract}

Palavras-chave: culinária, aplicativo, design.

Abstract: One of the features of modern world is the rapid and undeniable spread of information and communication technologies in society. This paper, entitled Amazon Flavors and Skills, is about a topic that involves the design of information and interaction, how the information may be available in a way that, in addition to acquiring knowledge, the user may have pleasant experiences. It presents the creation of interfaces for an application of Amazonian cookery for mobile devices, based on Jesse James 
Garret methodology. Conceptualizations of interaction design with an emphasis on ergonomics, usability and semiotics were applied. The results were mild and simple navigation interfaces, providing the most immediate feedback possible, and also an attractive visual language provided by the elements from the Amazonian cookery and culture.

Keywords: cookery, application, design.

\section{INTRODUÇÃO}

O presente artigo apresenta os resultados do trabalho acadêmico "INTERFACES PARA UM APLICATIVO SOBRE A CULINÁRIA DO AMAZONAS", desenvolvido por alunos do 5 o período na disciplina Projeto de Mídias Interativas de um curso de Design em Manaus-AM e posteriormente apresentado como Trabalho de Conclusão de Curso.

O projeto nasceu do pensamento de que pessoas interessadas na gastronomia do Amazonas poderiam ter interesse em obter além de receitas, outras informações relevantes sobre o assunto, como por exemplo, informações sobre os ingredientes para o preparo dos pratos, suas origens, propriedades terapêuticas, valores nutricionais e até mesmo onde os produtos poderiam ser comprados.

A partir de tal inquietação, o objetivo geral do trabalho foi criar um aplicativo para dispositivo móvel visando proporcionar de forma interativa as informações anteriormente citadas, minimizando tempo e aumentando a precisão e simplicidade de acesso sobre culinária do Amazonas.

Os objetivos específicos apontaram para pesquisas dos pratos típicos da região (origens e receitas), definição do publico alvo do projeto, análise de telas de aplicativos similares, estudos da plataforma do sistema operacional escolhido para o aplicativo e dos elementos da linguagem visual necessários para a construção das interfaces, além dos princípios e critérios ergonômicos em busca de uma boa usabilidade.

Para elaboração do projeto, realizou-se uma breve pesquisa de cunho exploratório e análises qualitativas, tendo como base as teorias dos campos da ergonomia e da linguagem visual (cor e forma, tipografia e semiótica). O produto final foi denominado "KUIAMAZÔNICA - guia da Culinária Amazônica".

\section{FUNDAMENTAÇÃO TEÓRICA}

\subsection{A Culinária Amazônica}

Como tema do projeto, a culinária foi compreendida como uma manifestação cultural, por sua forte influência na caracterização de um povo, no reconhecimento e representação dos costumes e hábitos de seus habitantes, na identificação do lugar ou região em que vivem. Pode-se considerar que o homem também é resultado de sua alimentação, e assim sendo, a questão dos alimentos não estão relacionadas apenas ao mercado, economia global, preços, custos e inflação. A alimentação está diretamente relacionada às questões culturais, sociais, como preferências, tolerâncias ou rejeições a determinadas comidas.

Alimentar-se é um ato nutricional, comer é um ato social, pois se constitui de atitudes, ligadas ao uso, costumes, protocolos, condutas e situações. 
Nenhum alimento que entra em nossa boca é neutro. A dimensão histórica da sensibilidade gastronômica explica e é explicada pelas manifestações culturais e sociais, como espelho de uma época (SANTOS, 2007, p. 112).

A culinária no Amazonas contém elementos da cultura indígena, cujo povo sempre preservou a natureza, respeitando-a pelos benefícios recebidos, nunca colocando em risco a estabilidade do meio ambiente amazônico. É uma cultura que se mescla com as heranças alimentares deixadas pelos portugueses, africanos e indianos, sendo o Atlântico porta de entrada e de saída de produtos, aproximando sabores às culturas nativas (SENAC, 2011).

Todas as grandes culinárias do mundo são formas de conhecimento, sistemas de sinais culturais transmitidos através do paladar e da inteligência. Um tempero sutil ou agressivo, a ênfase em certos aspectos do reino animal e a apresentação dos pratos são formas explícitas e reveladoras de uma civilização (SENAC, 2011, p. 13).

Explica-se assim, a sincronia entre essas heranças de diferentes povos, o que fez surgir os sabores amazônicos, tão apreciados pelo universo da gastronomia. Sabores oriundos da terra, nutritivos, cheios de saberes, reveladores de uma civilização e em vários casos, fontes de pesquisas da ciência, pela riqueza de nutrientes com fins terapêuticos.

Um desses casos é o guaraná, fruto semelhante a um olho (por trás disso existe uma lenda), celebrado entre indígenas, atletas e tantas pessoas como tendo propriedades energizantes e afrodisíacas.

Conforme Ribeiro (2011), na revista científica inglesa "Journal Phytotherapy Research", autor de uma pesquisa da Universidade Estadual do Amazonas (UEA) é relevante o poder das propriedades do guaraná no combate às síndromes metabólicas como hipertensão, diabetes, obesidade e dislipidemia. A pesquisa foi direcionada à população de Maués, município do Amazonas que é a terra do cultivo do guaraná, cuja população de idosos surpreende pela longevidade.

Outro exemplo é a graviola, fruto muito utilizado para chás, sucos, doces e sorvetes, com possíveis ações antioxidantes no organismo (RUGGIERO, 2007).

Os alimentos citados são apenas alguns de uma extensa lista da culinária amazônica, sendo conteúdos desta natureza que o produto criado pretende informar ao usuário.

\subsection{Ergonomia}

O projeto considerou a ergonomia como estudo imprescindível a uma boa interatividade entre o usuário e o aplicativo. De acordo com Cybis, Betiol e Faust (2007), a aplicação da ergonomia resulta em prazer a esse usuário, deixando-o à vontade para navegar e interagir facilmente com o dispositivo.

Frisou a importância de uma usabilidade eficiente e eficaz, através dos recursos de interação das interfaces que são as janelas, menus, botões, abas, formulários, etc., (metáforas do mundo real), enquanto os painéis de controle (manipulação, seleção, edição, informação), realizam a ação ou a tarefa. Requisitos necessários para a composição de um layout limpo, padronizado, com diagramação equilibrada, áreas 
livres e de conteúdos pertinentes e bem distribuídos (CYBIS; BETIOL; FAUST, 2010) também foram considerados.

Da mesma forma, o projeto seguiu as recomendações ergonômicas para a funcionalidade das interfaces. Para tal considerou que é papel da interface, "anteciparse e reagir às ações do usuário, convidando-o, apoiando-o durante suas ações e fornecendo-lhe respostas adequadas quanto ao andamento e ao resultado dessas ações" (CYBIS; BETIOL e FAUST, 2007, p.15).

Os critérios ergonômicos visaram proporcionar uma compreensão rápida das telas, pelo usuário (condução), uma leitura clara (legibilidade), uma resposta rápida (feedback imediato), uma economia de leitura e de memória (carga de trabalho), diferentes caminhos para funções (adaptabilidade), e informação de erros ao usuário (gestão de erro).

\title{
2.3 Semiótica
}

O projeto contemplou os princípios da Semiótica no design das interfaces e observando a linguagem dos signos como portadores de mensagens para auxílio na criação de telas intuitivas e agradáveis, com o objetivo de uma usabilidade eficiente e eficaz.

De acordo com Rozados e Alvarez (2013), o design de interação tem cada vez mais atenção com a concepção de sistemas, objetivando que sejam satisfatórios, agradáveis, divertidos, interessantes, úteis, motivadores, esteticamente apreciáveis, incentivadores, compensadores e emocionalmente adequados ao usuário. E para que todos esses requisitos sejam atendidos, a teoria dos signos é fator preponderante.

\begin{abstract}
A semiótica não é uma chave que abre para nós milagrosamente as portas de processos de signos cuja teoria e prática desconhecemos. Ela funciona como um mapa lógico que traça as linhas dos diferentes aspectos através dos quais uma análise deve ser conduzida, mas não nos traz conhecimento específico da história, teoria e prática de um determinado processo de signos. Sem conhecer a história de um sistema de signos e do contexto sociocultural em que ele se situa, não se pode detectar as marcas que o contexto deixa na mensagem. Se o repertório de informações do receptor é muito baixo, a semiótica não pode realizar para esse receptor o milagre de fazê-lo produzir interpretantes que vão além do senso comum (SANTAELLA, 2008, p. 6).
\end{abstract}

Assim, compreende-se junto com Bonsiepe (1997 apud PORTUGAL, 2010, p.4), que a interface deve ser entendida em um caráter mais amplo, desde sua ação instrumental, que é relacionada ao uso do produto, até sua ação comunicativa, que é o uso dos signos e informações (nas telas do dispositivo, as interfaces).

O usuário que interage com a interface percorre caminhos a partir de suas escolhas, com isso assinala um rastro, um caminho, uma documentação virtual. Estas escolhas são realizadas justamente a partir da comunicação gerada pelos signos presentes na tela, sendo as cores um dos mais relevantes neste processo.

Sobre um indivíduo que recebe a comunicação visual, a cor exerce uma ação tríplice: a de impressionar, a de expressar e de construir. A cor vista: impressiona a retina. E sentida: provoca uma emoção, e é construtiva, pois tendo um significado próprio, tem valor de símbolo e a capacidade, 
portanto, de construir uma linguagem que comunique uma ideia. (FARINA, PEREZ e BASTOS, 2006, p. 27).

Desta forma, no projeto do produto buscou-se aplicar signos reconhecíveis pelo usuário, mas que, ao mesmo tempo, também agissem como constituidores de novos conhecimentos; signos que, na dinâmica do uso, pudessem tanto despertar como possibilitar novas associações de significados.

\subsection{Tipografia}

A era digital chegou como uma ferramenta para o tipógrafo, possibilitando auxiliá-lo na criação de novas formas, deixando claro o seu papel (do tipógrafo) como criador (FARIAS, 2001). Pelo advento da tecnologia, conjuntos de formas - alfabéticas ou não - evoluem com facilidade para arquivos de fonte. Assim se deu a inclusão da tipografia no meio digital, proporcionando novas possibilidades para o designer e também, trazendo de volta o interesse por fontes e a antiga discussão sobre o principal tema da área: a legibilidade.

De acordo com Farias (2001), devem ser considerados, na seleção da fonte, aspectos históricos, técnicos e conceituais. Estando a tipografia entre os principais elementos para uma boa usabilidade, através da leiturabilidade e legibilidade, foram utilizadas no projeto, fontes de resgate de estilos claros e consistentes nos menus, a fim de que pudesse haver sintonia entre emissor, mensagem e receptor, num processo confortável de leitura e compreensão.

\section{METODOLOGIA}

A metodologia caracterizou-se como exploratória, de natureza aplicada e abordagem qualitativa. Para o projeto, baseou-se em Garret (2003), em seu diagrama dos elementos da experiência do usuário, que considera as teorias da Interação Humano - Computador $(\mathrm{HCl})$.

O método de Garret é proposto em 5 (cinco) planos conceituais, a saber: estratégia, escopo, estrutura, esqueleto e superfície. Segundo o autor, a construção do conteúdo deve usar uma abordagem conceitual partindo do abstrato para chegar à definição concreta, compreendida como o design visual apoiado na superfície gráfica do conteúdo.

No primeiro plano conceitual do método, a Estratégia, foi realizada uma pesquisa exploratória, não estruturada, do mercado de aplicativos de culinária na mídia em geral, visando entender os conteúdos acessados pelos usuários em sites de gastronomia. Neste plano foi definido um perfil de usuários e realizado um grupo focal. A partir deste, foram criados personas, determinados os objetivos do projeto e pesquisados produtos similares na web, visando à geração e seleção de ideias para concepção do primeiro wireframe.

Os sites similares pesquisados para estudo foram: "Casa e Comida", "Alta Gastronomia", "Receitas Maravilhosas" e "Tudo Gostoso". Pela orientação de indicar um perfil de produto que mais se aproximasse do pretendido pelos projetistas, o escolhido foi o "Tudo Gostoso". O motivo da escolha deveu-se à quantidade de acertos quanto à interatividade analisada pela equipe. A interface do aplicativo Tudo Gostoso é baseada no site de mesmo nome, com os mesmos conteúdos, porém com o cuidado de admitir uma interface única. 
No segundo plano, o Escopo, foi realizada a caracterização do aplicativo, já iniciando uma fase mais concreta do diagrama de Garret. Neste momento, foram definidos os requisitos para criação das interfaces (wireframes de baixa resolução, fluxo, menus, pontos interativos e transição de telas), definidos também os requisitos dos conteúdos (textos, imagens, áudio e vídeo) e especificadas as partes funcionais por meio das informações para cada tela (otimização nas buscas e navegação) e pelos conteúdos (uso de wireframes, composição de tipografia e disposição de imagens).

No plano 3, da Estrutura, foram definidos a organização, agrupamento e apresentação dos conteúdos. Foi criado um design de interação entre produto e usuário, com caráter sequencial e harmônico, conforme fluxograma. Foi determinado, também o número de telas de cada item na barra de navegação. Nessa etapa foi aplicada a técnica de card-sorting para a arquitetura de informações e bordagens dos conteúdos em estrutura hierárquica, além de escolhida a forma de apresentação das telas.

No plano 4, do Esqueleto, foi definida a apresentação dos conteúdos nas interfaces (tamanho e forma dos botões, espaço), desenvolvido o design das telas propriamente dito, os links, as áreas de conteúdos, os atalhos, os banners, as barras de localização e de navegação, incluindo as ferramentas de buscas e menus. O layout foi definido pelos wireframes sempre em busca de um design consistente e de um feedback claro e imediato.

No último plano da metodologia de Garret, da Superfície, foi criado o design visual para representar todas as informações. Foram definidas a paleta de cores, a tipografia e a estética dos botões e demais elementos indicativos.

Como requisito de software, o Kuiamazônica foi pensado e projetado como aplicativo Android, pelas opções de recursos disponibilizados pelo sistema, e pelo tempo para realizar uma determinada ação, o que levará o usuário a obter resultados a contento, situando-o em uma "zona de conforto".

\section{DESENVOLVIMENTO DO APLICATIVO}

A experiência do usuário é quem dá as respostas às perguntas sobre a funcionalidade do aplicativo intitulado KUIAMAZÔNICA - guia da culinária Amazônica.

Segundo George (2013), essa experiência é composta por três fatores: foco, percepção e funcionalidade, os quais juntos dão ao visitante uma percepção completa da marca na interface do aplicativo. O foco faz com que o usuário interaja com os conteúdos, participe do processo desejando experimentar o produto e compartilhar informações, dirigindo-se aos conteúdos. A percepção das interfaces, por suas cores, fontes, e imagens uniformes é imediata. E para a funcionalidade, é preciso ter sempre em mente a ação que o usuário quer executar.

Os botões, as características interativas e formas nas interfaces do aplicativo Kuiamazônica buscaram sempre apresentar objetivos claros e atraentes, pois "Interface é um dispositivo que estabelece comunicação entre dois sistemas distintos, com a função de facilitar e intermediar essa troca de informações para que a tarefa seja executada com eficiência" (SCHULENBURG; PEZZINI, 2013, p.200).

Assim, entende-se que o real benefício do design não é apenas ser bonito ou ser útil e sim melhorar e aperfeiçoar a identificação do usuário com o produto, nesse caso com as interfaces do aplicativo, tal qual se apresenta a seguir nas telas de 
resultado final do produto. A figura 1 apresenta a tela inicial do aplicativo, seguida da tela Ajuda/Tour.

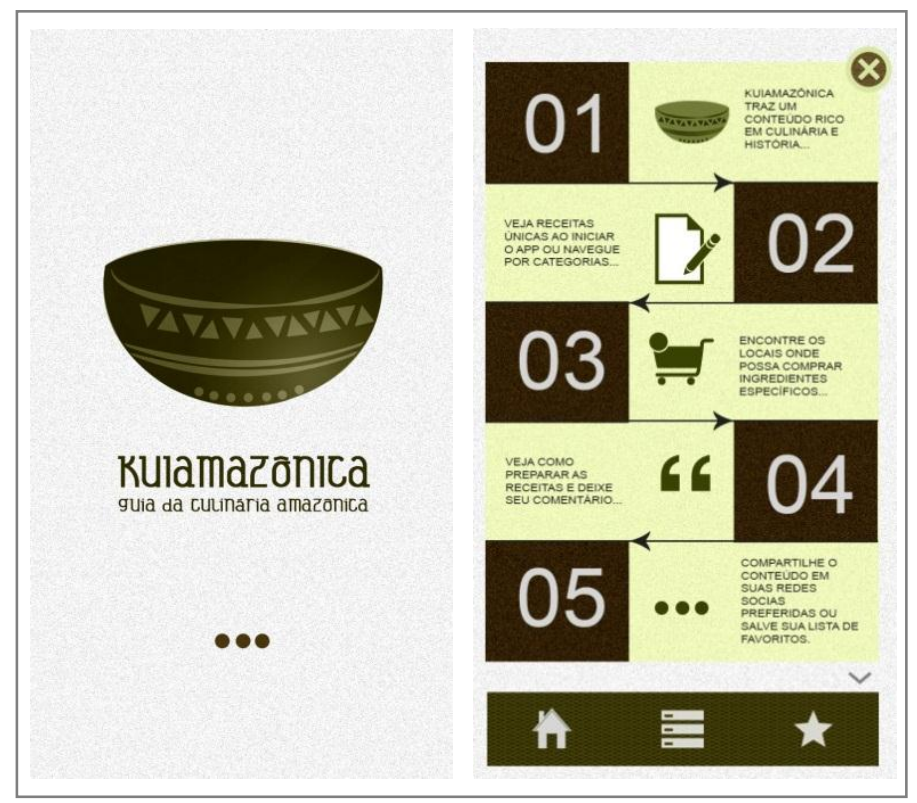

Figura 1 - Tela inicial e tela Ajuda.

Fonte: Elaborado pelo autor, com base na pesquisa realizada.

As cores definidas para o projeto - verde, marrom e branco - foram estudadas para chamar a atenção do usuário e indicar os aspectos das interfaces projetadas para o aplicativo de culinária do Amazonas. A cor verde, aplicada nas barras de navegação global superior e inferior das telas, foi utilizada para manter a identidade visual do aplicativo. Seu tom escuro remete ao equilíbrio, à ecologia, à floresta amazônica, ao regional. $\mathrm{O}$ marrom é a cor associada à terra, à resistência, ao vigor, às origens, de onde vem os alimentos e foi aplicada como plano de fundo para as informações de cada menu. A cor branca, de simbologia neutra, clara, de ordem, foi utilizada na tipografia da marca, nas delimitações das áreas de conteúdos e nos ícones dos rodapés, para gerar contraste e possibilitar visibilidade ao máximo.

A marca do aplicativo, uma cuia (artefato indígena para colocar alimentos), possui forma de meio círculo, é oriunda de um fruto da floresta, em sua forma inicial. Recebeu também as cores verde, marrom e branco, símbolos fortes ligados a terra. As demais formas concebidas para todas as estruturas do aplicativo Kuiamazônica, derivaram do encontro de linhas retas horizontais e verticais, da forma quadrada. Essa concepção passa ao usuário tradição, solidez, segurança, firmeza, proteção.

Para a navegabilidade $(\mathrm{HCl})$ com referencia ao layout das telas seguintes (vide figura 2), foram usados padrões primários de navegação: abas para o menu padrão de navegação como home, lista e favoritos; menu de lista para os conteúdos dos aplicativos como as receitas por categorias e metáfora, aplicada somente para o aspecto visual das telas. 


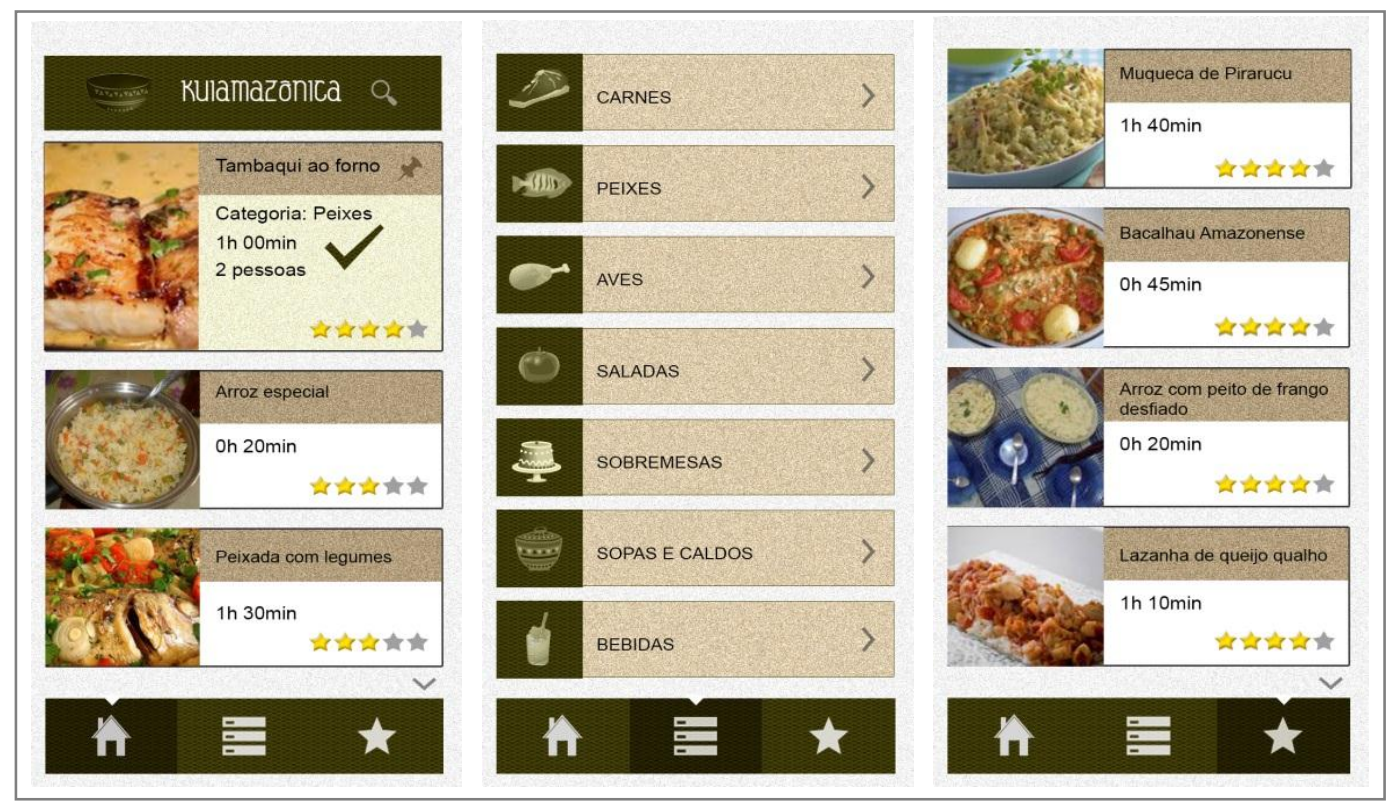

Figura 2 - Telas padrões primários de navegação.

Fonte: Elaborado pelo autor, com base na pesquisa realizada.

Partindo do prato culinário selecionado, foram projetadas as telas e disponibilizadas as abas com informações detalhadas no que diz respeito às receitas, aos ingredientes, onde comprar, modo de preparo, tempo de preparo e comentários, conforme ilustra as figuras 3 e 4.

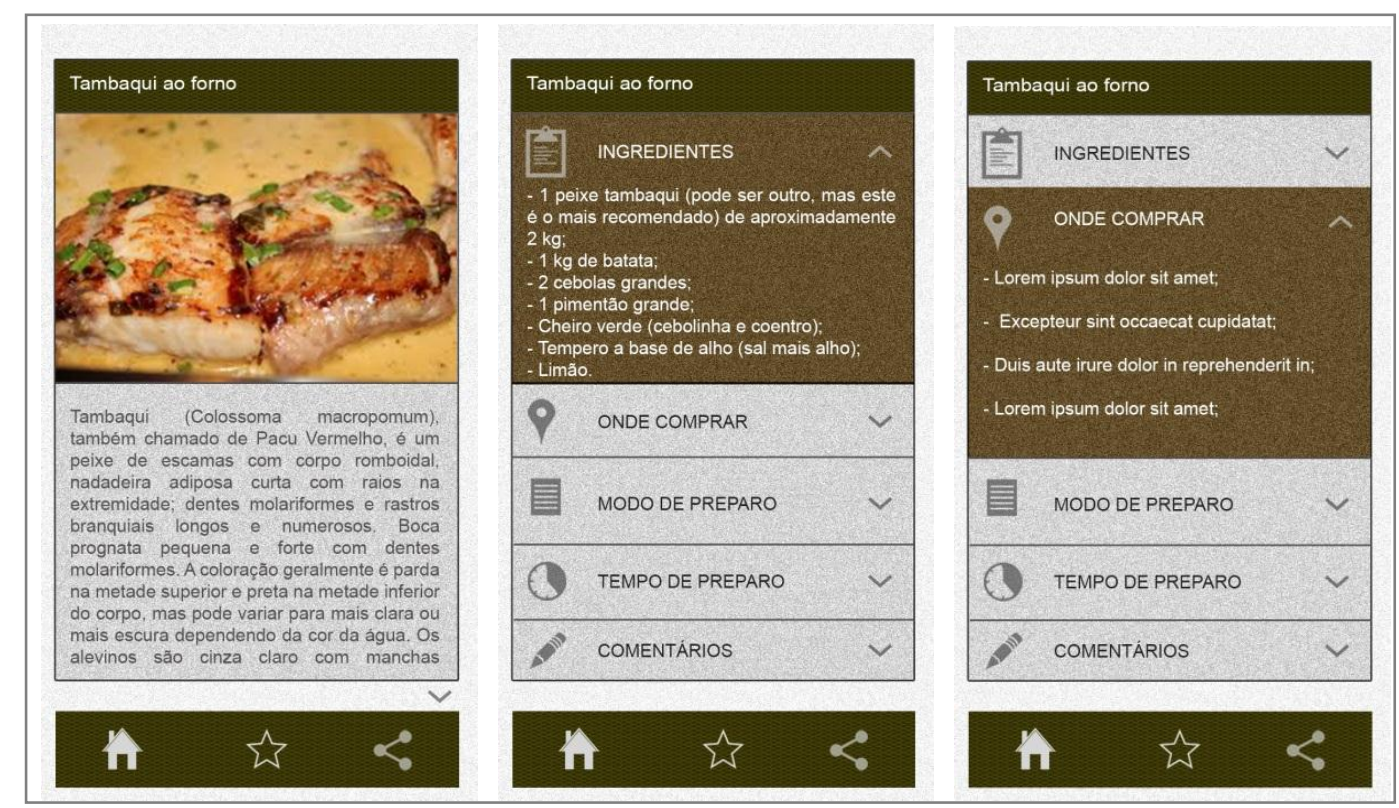

Figura 3 - Prato escolhido e ingredientes.

Fonte: Elaborado pelo autor, com base na pesquisa realizada. 


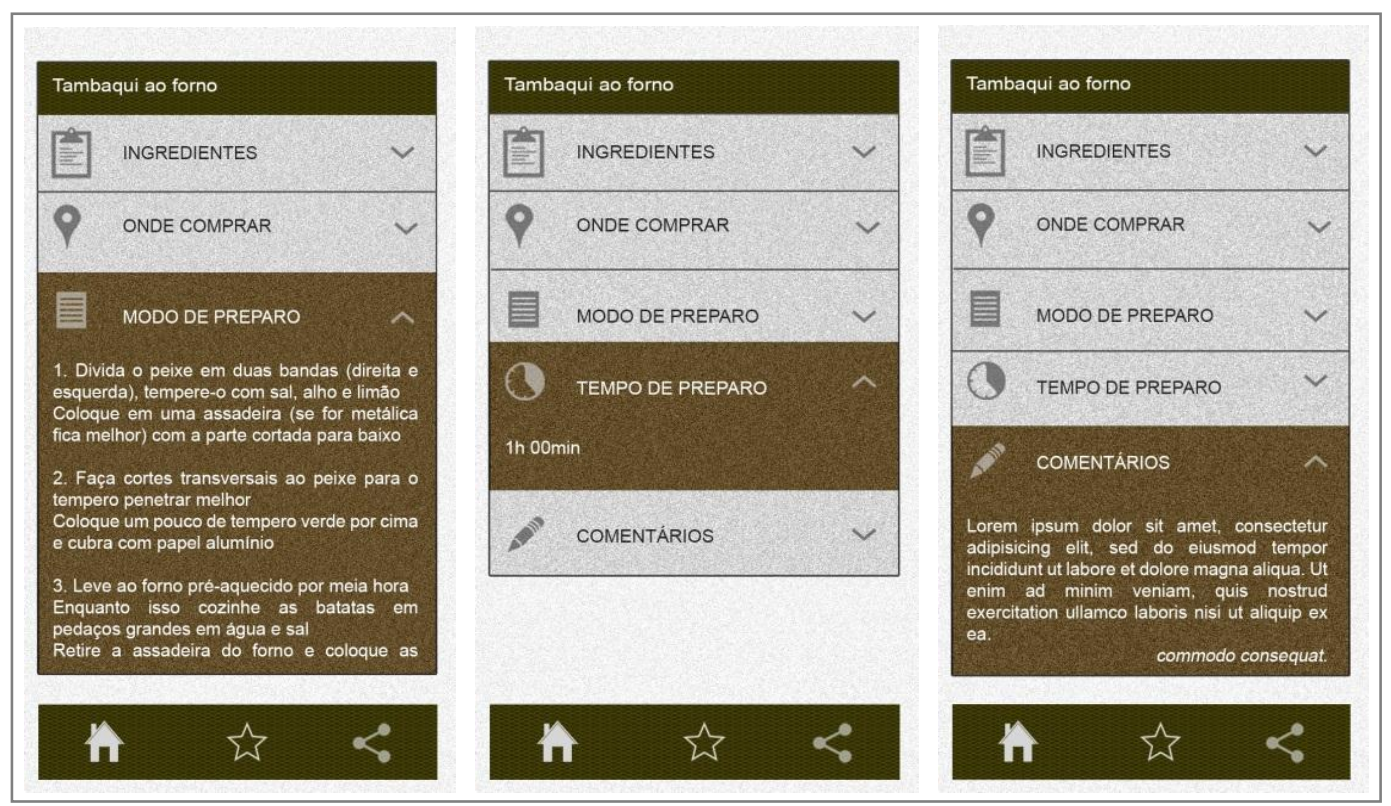

Figura 4 - Preparação e comentários.

Fonte: Elaborado pelo autor, com base na pesquisa realizada.

A última tela apresentou ainda a possibilidade de compartilhar nas redes sociais, indicar e socializar a sua experiência.

Para escolha dos elementos cromáticos foram considerados aspectos como: impacto, visibilidade, o significado do signo (cor) em si. Os ícones apresentaram características de metáfora e poder de sugestão e de associação pela aparência, visando melhor compreensão e assimilação.

As interfaces do aplicativo contém diálogo simples, com características regionais do Amazonas nos conteúdos, não apresenta sobrecarga de memória para o usuário, é consistente, proporciona feedback imediato, saídas fáceis, atalhos, prevenção de erros e ajuda.

Analisadas as telas das interfaces e avaliadas suas funções dentro do fluxograma (vide figura 5), o resultado foi a objetividade nos menus, para fazer jus aos seus objetivos de apresentar os pratos típicos do Amazonas, suas origens e receitas, criando meios para que o usuário pudesse postar, pesquisar e compartilhar fotos e textos.

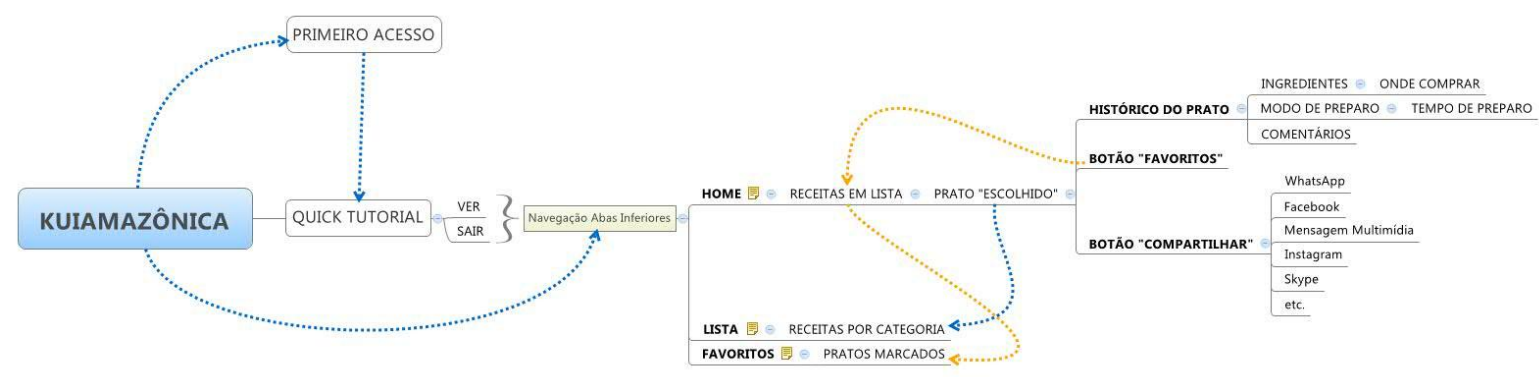

Figura 5 - Fluxograma do Aplicativo.

Fonte: Elaborado pelo autor, com base na pesquisa realizada. 


\section{CONCLUSÃO}

O objetivo deste artigo foi apresentar o processo de criação e resultado final do aplicativo KUIAMAZÔNICA, no que diz respeito ao design de suas interfaces, com ênfase para a usabilidade em dispositivos móveis, observados os critérios ergonômicos e semióticos utilizados em sua composição.

De acordo com Gil, Oliva e Gaspar (2008), um produto apresentado no trabalho com conceito regional, representa um conjunto de coisas vinculadas a uma história, a circunstâncias de uma determinada região em torno de sua cultura, sentimentos e problemas, e, de certa forma, a todo tempo esta preocupação fez parte do processo criativo.

Todavia, é sabido que, para que se possa considerar um projeto de design de interação como finalizado para produção, um ciclo de testes e revisões deve ser realizado, pois "O design de interação não é um conceito e, dessa forma, só é bom se relacionado à filosofia do design centrado no usuário, em que o público final do produto é ouvido em todo o seu desenvolvimento"(ARNOLD, 2010, apud SANTOS, 2010, p. 6).

Pelo processo e resultado final exposto, considera-se que o projeto possibilitou relevante experiência para a equipe acadêmica, uma vez que se teve a possibilidade de lidar com um método de projeto relacionado às novas tecnologias, bem como, técnicas diferenciadas de análise e criação de soluções.

Este processo proporcionou à equipe a segurança necessária à concepção do produto, uma vez que este foi plenamente fundamentado e construído em bases consistentes e honestas de conceituações do design de informação e interação.

\section{REFERÊNCIAS}

CYBIS, Walter; BETIOL, Adriana; FAUST, Richard. Ergonomia e usabilidade: Conhecimento, Métodos e Aplicações. 2.ed.São Paulo: NOVATEC, 2007.

FARIAS, Priscila. Tipografia digital: o impacto das novas tecnologias. 3.ed. Rio de Janeiro: 2AB, 2001.

FARINA, Modesto; PEREZ, Clotilde; BASTOS, Dorinho. Psicodinâmica das Cores em comunicação. 5.ed. São Paulo: Edgar Blucher, 2006.

GARRET, James. The elements of user experience: user, centered design for the web. USA: New Riders, 2003.

GEORGE, David. As 3 principais características do design de um site que vende. Disponível em: <http:/www.hytrade.com.br/estrategia/as-3-principais>. Acesso em: 05 nov. 2013.

GIL, Antonio Carlos; OLIVA, Eduardo de Camargo; GASPAR, Marcos Antonio. A regionalidade como área de estudo da administração: um estudo de caso de um programa de mestrado em administração. Revista Gestão.Org, São Caetano do Sul, edição $\quad$ especial, $2008 . \quad$ Disponível em 
<http:/www.repositorio.uscs.edu.br/bitstream/123456789/99>. Acesso em 04 nov. 2013.

PORTUGAL, Cristina. Questões complexas do design da informação e de interação. InfoDesign, São Paulo, v.7, n.2, 2010. Disponível em: <http//www.infodesign.org.br/>. Acesso em 03 nov. 2013.

RIBEIRO, Euler et. al. Habitual intake of guaraná and metabolic morbidities: evidence from na epidemiological study of an elderly Amazonian population. In: Journal Phytotherapy Research. 2011. Disponível em: <http:/www.diabetenet.com.br/conteudocompleto. asp?idconteudo> Acesso em 04 nov. 2013.

ROZADOS, Helen; ALVAREZ, Gonzalo. Sistemas eletrônicos de editoração de periódicos científicos e a questão da usabilidade. Revista ACB, Santa Catarina, v.18, n.2, 2013. Disponível em: <http://www.revista.acbsc.org.br>. Acesso em 06 nov. 2013.

RUGGIERO, Ana Célia et. al. Avaliação da capacidade antioxidante dos extratos e suas frações de graviola (Annona Muricata), Pau D arco (Tabebula Avelanedae), Pariparoba (Pipper $\quad$ Rgnelli). $2007 . \quad$ Disponível em <http:/www.unimep.br/phpg/mostraacademica/anais>. Acesso em 05 nov. 2013.

SANTAELLA, Lúcia; NOTH, Winfried. Imagem: cognição, semiótica, mídia. São Paulo: Iluminuras, 2008.

SANTOS, Bruno. A importância do design para tornar as redes sociais mais interativas. Texto livre linguagem e tecnologia, Minas Gerais, v.6, n.1, 2013. Disponível em: <http://www.periodicos.letras.ufmg.br/>. Acesso em 07 nov. 2013.

SANTOS, Carlos. Histórias da alimentação no Paraná. Curitiba: Juruá, 2010.

SCHULENBURG, Ray; PEZZINI, Marina. Sistematização de conceitos ergonômicos e semióticos para projetos de interfaces gráficas do usuário. Projética, Londrina, v.4, n.1, 2013. Disponível em: <http://www.vel.br/revistas>. Acesso em 07 nov. 2013.

SENAC. Culinária amazônica: o sabor da natureza. Rio de Janeiro: Senac Nacional, 2011. 